УДК 004.42:535.361

DOI: $10.25140 / 2411-5363-2020-3(21)-154-162$

\author{
Сергій Точилін
}

\title{
ПРИКЛАДНЕ ПРОГРАМНЕ ЗАБЕЗПЕЧЕННЯ ДЛЯ ОПТОВОЛОКОННОГО ЦИФРОВОГО СПЕКТРОМЕТРА ВТС-110S
}

Актуальність теми дослідження. Спектральні прилади иироко використовуються в наукових та прикладних оптичних дослідженнях. Сучасні спектральні прилади в багатьох випадках є ијифровими. Розробка прикладного програмного забезпечення (ПЗ) для иифрових спектральних приладів є актуальним завданням.

Постановка проблеми. Здебільшого компанії, які виготовляють спектральне устаткування, поставляють цฺифрові спектральні прилади і прикладне ПЗ в комплекті. У багатьох випадках використання иього ПЗ прив'язано до певної платформи. Подібні особливості має прикладне програмне забезпечення для спектрометра BTC-110S. Kрім того, ПЗ, яке поставлясться разом із приладами, може не включати необхідних для оптичних досліджень проџедур обробки спектральних даних.

Аналіз останніх досліджень і публікацій. У наш час однією з найбільш популярних мов програмування є Јаvа. Останнім часом мовою програмування Јаvа розроблена кросплатформна програма ST Сотрlех - прикладне ПЗ для спектрометра BTC-110S.

Виділення недосліджених частин загальної проблеми. Програма ST Сотрlех має певні обмеження. Вона дозволяє спектрометру BTC-110S реєструвати спектри випромінювання тільки в однократному режимі. Крім того, при обробиі спектральних даних відсутня можливість знаходження результатів множення та ділення спектрів один на одного, а також визначення кореляиійного спектра та його коефіиієнта відповідності.

Постановка завдання. Розробити Јаvа-додаток, який може використовуватися для реєстраиї̈ спектрометром BTC-110S спектрів випромінювання в однократному та безперервному режимі, а також для кількісного порівняння $i$ обробки за допомогою арифметичних операчій спектральних даних об'єктів дослідження. При иьому для порівняння спектрів джерел оптичного випромінювання використовувати різницеві та корелячійні спектри, а також їхні коефіиієнти відповідності.

Виклад основного матеріалу. Описані особливості функціонування та графічний інтерфейс користувача Јаvадодатка, що вирішує поставлене завдання. Наведені приклади його використання.

Висновки відповідно до статmі. Розроблено кросплатформне прикладне ПЗ для реєстраиії спектрометром BTC-110S спектрів випромінювання в однократному та безперервному режимі, а також для кількісного порівняння $i$ обробки за допомогою арифметичних операиій спектральних даних об'єктів дослідження. 3 порівняння спектрів об'єктів дослідження програмою визначаються коефічієнти відповідності для їх різницевого та корелячійного спектра.

Ключові слова: спектрометр; спектр; прикладне програмне забезпечення.

Рис.: 5. Бібл.: 8

Актуальність теми дослідження. Оптичний спектральний аналіз широко використовується в наукових і прикладних дослідженнях. Аналіз проводять на основі спектрів, які зареєстровані спектральними приладами, що працюють у діапазоні довжин хвиль оптичного випромінювання.

Сучасні спектральні прилади в багатьох випадках є цифровими. Керування їхньою роботою, а також прийом та обробка даних спектральних вимірів, здійснюється прикладним програмним забезпеченням (ПЗ).

При цьому розробка прикладного ПЗ для спектральних приладів є актуальним завданням.

Постановка проблеми. Компанії, які виготовляють спектральне устаткування, переважно поставляють цифрові спектральні прилади й комп'ютерні програми для їх використання (прикладне ПЗ) у комплекті. У багатьох випадках використання цих програм жорстко прив' язано до певної платформи. Подібні особливості має прикладне програмне забезпечення для цифрового оптоволоконного спектрометра BTC-110S [1], функціональні можливості якого описані в [2].

Крім того, програмне забезпечення, яке поставляється разом із приладами, може не включати необхідних для оптичних досліджень процедур обробки спектральних даних.

При цьому розробка кросплатформного прикладного програмного забезпечення для цифрових спектральних приладів, зокрема і для BTC-110S, яке управляє їхньою роботою, реєструє та обробляє спектри джерел оптичного випромінювання за допомогою необхідних процедур, є актуальною проблемою.

() Точилін С. Д., 2020 
TECHNICAL SCIENCES AND TECHNOLOGIES

Аналіз останніх досліджень і публікацій. У роботах [3; 4] повідомляється про розробку прикладного ПЗ для спектрометра BTC-110S.

При цьому в [3] також наведені характеристики та команди керування для цього цифрового оптоволоконного спектрального приладу.

У той час в [4] описаний кросплатформний програмний комплекс для BTC-110S, що був створений за допомогою мови програмування $\mathrm{C}++$. Він, зокрема, забезпечує реєстрацію приладом спектрів джерел оптичного випромінювання як в однократному, так і в безперервному режимі, а також дозволяє виконувати над ними математичні операції, у тому числі й арифметичні (додавання, вирахування, множення, ділення).

Останнім часом при оптичних дослідженнях для кількісного порівняння спектрів вторинного випромінювання (CBB) різних речовин використовують їх різницевий спектр (PC) $J_{X}^{E}(\lambda)$, відповідно до $[5,6]$ його визначають за допомогою виразу:

$$
I_{X}^{E}(\lambda)=1-\left|I_{X}(\lambda)-I_{E}(\lambda)\right|=1-\left|\frac{I_{X}^{\prime}(\lambda)}{I_{X \max }^{\prime}}-\frac{I_{E}^{\prime}(\lambda)}{I_{E \max }^{\prime}}\right|,
$$

де $\lambda$ - довжина хвилі, $I_{X}(\lambda)$ і $I_{E}(\lambda)$ - нормовані СВВ для речовини $(X)$, яку аналізують, та еталонної речовини $(E)$ відповідно, $I_{X}^{\prime}(\lambda), I_{E}^{\prime}(\lambda), I_{X \max }^{\prime}, I_{E \max }^{\prime}$ - зареєстровані спектри для речовини, що досліджують, і еталонної речовини, а також їх максимальні значення відповідно.

Оцінка ідентичності або відмінності спектрів $I_{X}(\lambda)$ та $I_{E}(\lambda)$ здійснюється за допомогою коефіцієнта відповідності $K_{d}[5 ; 6]$ :

$$
K_{d}=\frac{1}{N} \sum_{i=1}^{N}\left(1-\left|I_{X}(\lambda)-I_{E}(\lambda)\right|\right)_{i}=\frac{1}{N} \sum_{i=1}^{N} I_{X}^{E}\left(\lambda_{i}\right),
$$

де $N$ - число замкнутих інтервалів $\Delta \lambda$ у спектральному діапазоні довжин хвиль від $\lambda_{I}$ до $\lambda_{I I}$ із шириною $B, B=\lambda_{I I}-\lambda_{I}, \quad N=B / \Delta \lambda$.

Відповідно до (2), при $\Delta \lambda \rightarrow 0$, коефіцієнт $K_{d}$ має значення:

$$
K_{d}=\frac{1}{B} \int_{\lambda_{I}}^{\lambda_{I I}} I_{X}^{E}(\lambda) d \lambda
$$

Згідно з (3) $K_{d}$ - середне значення різницевого спектра в діапазоні довжин хвиль від $\lambda_{I}$ до $\lambda_{I I}$.

У той час певний інтерес при порівнянні $I_{X}^{\prime}(\lambda)$ та $I_{E}^{\prime}(\lambda)$ в діапазоні довжин хвиль від $\lambda_{I}$ до $\lambda_{I I}$, на якому $I_{E}^{\prime}(\lambda)$ не містить нульових значень, має кореляційний спектр (КС) $J_{X}^{E}(\lambda)$, що визначається виразом:

$$
J_{X}^{E}(\lambda)=1-\left|\frac{J_{X}(\lambda)-J_{E}(\lambda)}{J_{E}(\lambda)}\right|=1-\left|\frac{\left(I_{X}^{\prime}(\lambda) / I_{X E}^{\prime}\right)-\left(I_{E}^{\prime}(\lambda) / I_{E E}^{\prime}\right)}{\left(I_{E}^{\prime}(\lambda) / I_{E E}^{\prime}\right)}\right|,
$$

де $J_{X}(\lambda), J_{E}(\lambda)$ - нормовані за значеннями $I_{X E}^{\prime}$ та $I_{E E}^{\prime}$ спектри $I_{X}^{\prime}(\lambda)$ й $I_{E}^{\prime}(\lambda)$ відповідно, $I_{X E}^{\prime}, I_{E E}^{\prime}-$ інтенсивність на певній, характерній для даного еталона довжині хвилі $\lambda_{E}\left(\lambda_{I} \leq \lambda_{E} \leq \lambda_{I I}\right)$ для спектрів $I_{X}^{\prime}(\lambda)$ і $I_{E}^{\prime}(\lambda)$ відповідно. 
При цьому оцінка ідентичності або відмінності об'єктів дослідження з еталоном на основі (4) здійснюється за допомогою коефіцієнта відповідності $K_{c}$ (середнього значення КС у спектральному діапазоні від $\lambda_{I}$ до $\left.\lambda_{I I}\right)$ :

$$
K_{c}=\frac{1}{B} \int_{\lambda_{I}}^{\lambda_{I I}} J_{X}^{E}(\lambda) d \lambda .
$$

Для реєстрації спектрів вторинного випромінювання поряд зі спектрометрами широко використовують світлофільтри. При цьому загальне пропущення $\tau(\lambda)$ спектральної установки дозволяє виділяти інтервал довжин хвиль необхідний для реєстрації спектрів об’єктів дослідження при придушенні збудливого випромінювання.

У той час характерною рисою $J_{X}^{E}(\lambda)$ та $K_{c}$, які визначаються виразами (4) та (5), відповідно, є їх незмінність для різних $\tau(\lambda)$.

При цьому $I_{X}^{E}(\lambda)$ й $K_{d}$, які розраховують із використанням (1) та (3), відповідно, подібної особливості не мають.

Відзначимо також, що вирази (1), (3), (4), (5) можна використовувати і для порівняння оптичних спектрів джерел первинного випромінювання.

Крім того, при дослідженні особливостей $I_{X}^{\prime}(\lambda)$ і $I_{E}^{\prime}(\lambda)$ певний інтерес мають і дані про екстремальні значення $I_{X}^{E}(\lambda)$ та $J_{X}^{E}(\lambda)$.

У наш час однією з найбільш популярних мов програмування, відповідно до індексу TIOBE [7], є Јava ${ }^{\mathrm{TM}}$. Вона кросплатформна і широко використовується в прикладних цілях. Java має розвинений API, який вільно поширюється.

У роботі [8] мовою програмування Јava нами була розроблена програма ST_Complex - прикладне ПЗ для спектрометра BTC-110S.

Виділення недосліджених частин загальної проблеми. Програма ST_Complex мала певні обмежень, зокрема, під іï керуванням спектрометр BTC-110S міг реєструвати спектри джерел оптичного випромінювання тільки в однократному режимі.

Крім того, при обробці експериментальних даних була відсутня можливість знаходження результатів множення та ділення спектрів один на одного, а також визначення $J_{X}^{E}(\lambda)$ i $K_{c}$.

Постановка завдання. У цій роботі була поставлено завдання розробки за допомогою мови програмування Јava кросплатформного прикладного ПЗ, яке може використовуватися для реєстрації спектрометром ВТC-110S спектрів джерел оптичного випромінювання в однократному та безперервному режимі, а також кількісного порівняння і обробки за допомогою арифметичних операцій спектральних даних об'єктів дослідження.

При цьому для кількісного порівняння спектрів джерел оптичного випромінювання передбачалося використовувати вирази (1), (3), (4) та (5).

Виклад основного матеріалу. Для вирішення поставленого завдання був створений Java-додаток DS_Complex, який при роботі зі спектрометром BTC-110S використовував інтерфейс RS-232 та протокол ASCII. Програма мала графічний інтерфейс користувача (Graphical User Interface - GUI), що розташовувався на панелі із вкладками: «Registration», «Matching» та «Processing».

Набір компонентів GUI вкладки «Registration» використовувався для керування процесом реєстрації спектрів джерел оптичного випромінювання спектрометром BTC-110S, а також відображення спектральних даних. На початку роботи з ним за допомогою списку, який розкривається, та кнопки «Рort» вибирався COM-порт спектрометра, а при натисканні на кнопку «Тіте» задавався час експозиції спектра (у мілісекундах), чисельне значення якого попередньо встановлювалося в полі вводу. 
TECHNICAL SCIENCES AND TECHNOLOGIES

Процес реєстрації здійснювалася після натискання на кнопку «Run». При цьому необхідні для роботи програми коефіцієнти, які визначають калібрування BTC-110S по довжинах хвиль, знаходилися у файлі Coefficients.csv.

У випадку «включення» прапорця «Lоор» реалізовувався багаторазовий режим реєстрації, при «виключенні» - однократний. При роботі спектрометра під час реєстрації в багаторазовому режимі кнопка «Run» мала назву «Stop» та використовувалася для зупинки цього процесу.

Зареєстрований спектр відображався на панелі додатка в графічному вигляді. При «включенні» прапорця «Тable» дані спектральних вимірів могли додатково представлятися і у табличному вигляді.

Крім того, спектральні дані можна було зберегти у файлах формату *.csv і при необхідності одержати до них доступ за допомогою меню «File».

У той час інформація про створений Јаvа-додаток та особливостях його роботи була доступна при використанні меню «Неlp».

На рис. 1, як приклад, зображено вікно програми DS_Complex зі спектром фотолюмінесценції (ФЛ) жовтого кольорового паперу, на рис. 2 - червоного.

ФЛ кольорового паперу збуджувалася фіолетовим лазером 3 довжиною хвилі випромінювання 405 нм. При реєстрації її спектрів використовувався абсорбційний світлофільтр ЖЗС5 завтовшки 2 мм.

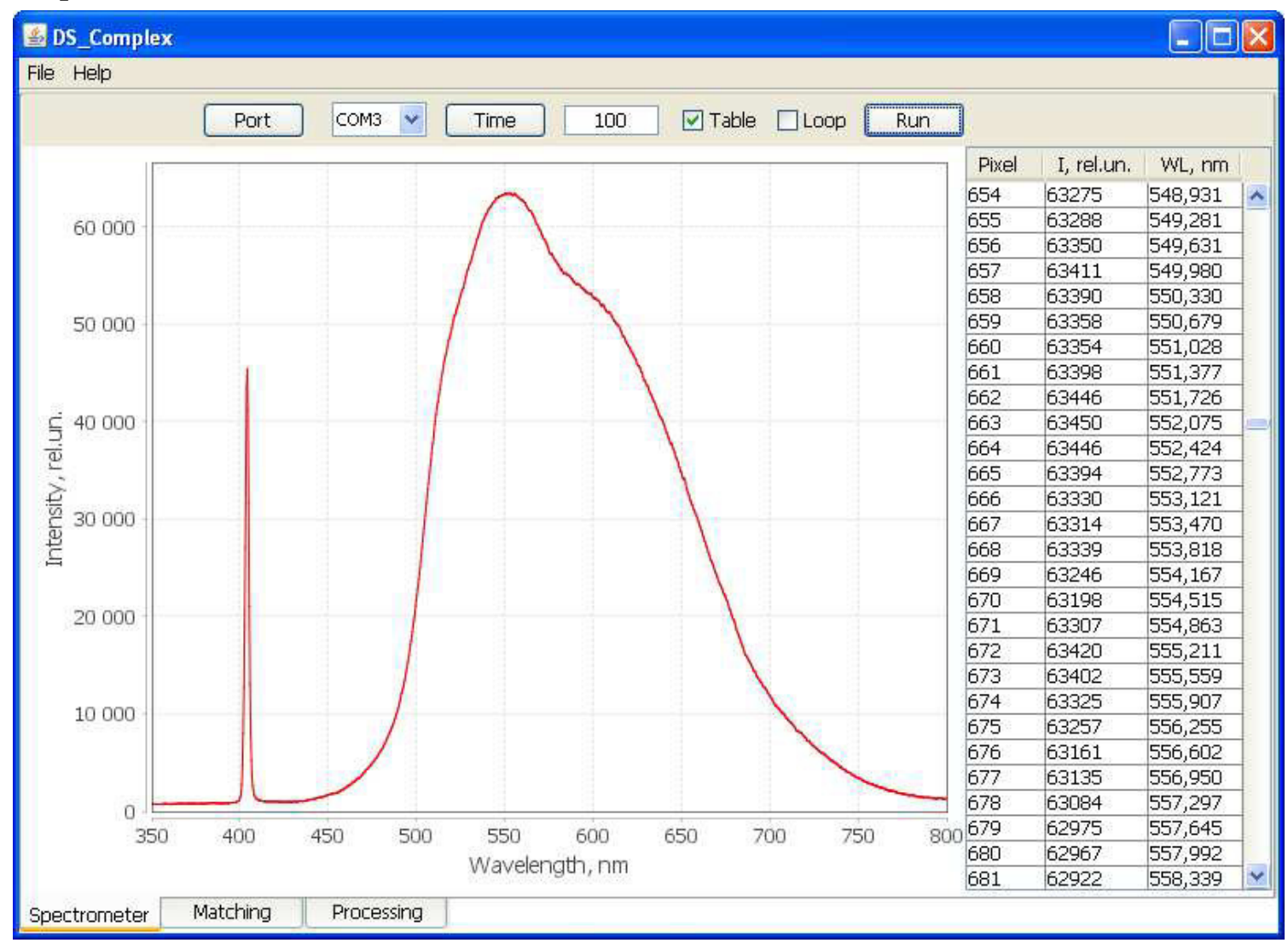

Puс. 1. Вікно програми DS_Complex зі спектром ФЛ жовтого паперу

Набір компонентів GUI програми DS_Complex, що розташовувався на вкладці «Matching», використовувався для формування та обробки РС і КС на основі спектрів, які були зареєстровані спектрометром BTC-110S. 
TECHNICAL SCIENCES AND TECHNOLOGIES

При роботі з ним за допомогою меню «File» спектри оптичного випромінювання (COB) еталонного об'єкта та об'єкта аналізу завантажувалися з *.csv файлів і відображалися на панелі додатка. Вибір формування та обробки РС або КС визначався за допомогою прапорців «I(WL)» i «J(WL)» відповідно.

У той час для ініціалізації значеннь $\lambda_{I}$ і $\lambda_{I I}$ спектрального діапазону РС або КС використовувалися поля вводу «Low value» та «High value» відповідно.

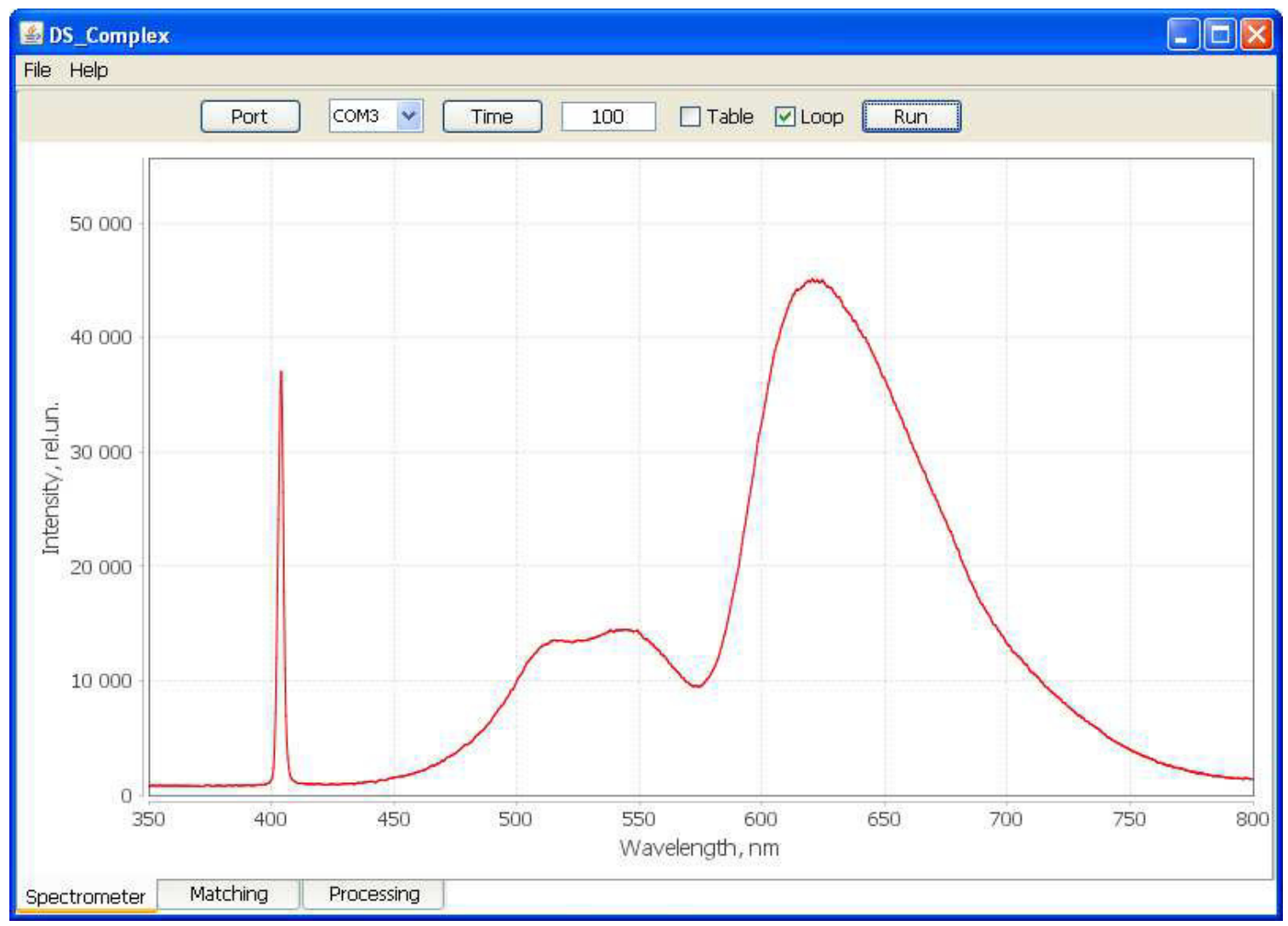

Puс. 2. Вікно програми DS_Coтрleх зі спектром ФЛ червоного паперу

При включеному прапорці «I(WL)», після натискання на кнопку «Calculate», програма DS_Complex розраховувала різницевий спектр. Потім виконувала його чисельне інтегрування зі змінним кроком та розрахунок коефіцієнта $K_{d} 3$ використанням виразу (3). Крім того, визначала мінімальне $I_{\min }$ та максимальне значення $I_{\text {max }}$ залежності $I_{X}^{E}(\lambda)$. При цьому РС відображався на панелі додатка в графічному вигляді, а значення $K_{d}, I_{\max }$ та $I_{\min }$ 3'являлися в полях вводу «Кd», «Imax» i «Imin» відповідно.

Спектральні дані $I_{X}^{E}(\lambda)$ поміщалися в таблицю додатка. У ній фон рядків із параметрами екстремумів РС здобував сірий колір.

$\mathrm{У}$ той час при включеному прапорці «J(WL)», після натискання на кнопку «Calculate», програма DS_Complex провадила розрахунок КС та обробку його спектральних даних. При цьому значення коефіцієнта $K_{c}$ визначалося за допомогою виразу (5).

КС відображався на панелі додатка в графічному вигляді, а значення $K_{c}, J_{\max }$ i $J_{\min }$ з'являлися в полях вводу « $K_{c} », \ll J_{\max } » \mathrm{i} « J_{\min } »$ відповідно, а дані $J_{X}^{E}(\lambda)$ поміщалися в таблицю додатка.

Крім того, розроблений додаток дозволяє зберегти PC і КС у файлах формату *.csV та за необхідності одержати до них доступ за допомогою меню «File». 
TECHNICAL SCIENCES AND TECHNOLOGIES

На рис. 3 як приклад зображене вікно програми DS_Complex iз PC і значеннями $K_{d}$, $I_{\max }$ та $I_{\min }$, на рис. 4 вікно із $\mathrm{KC} \mathrm{і} K_{c}, J_{\max }, J_{\min }$.

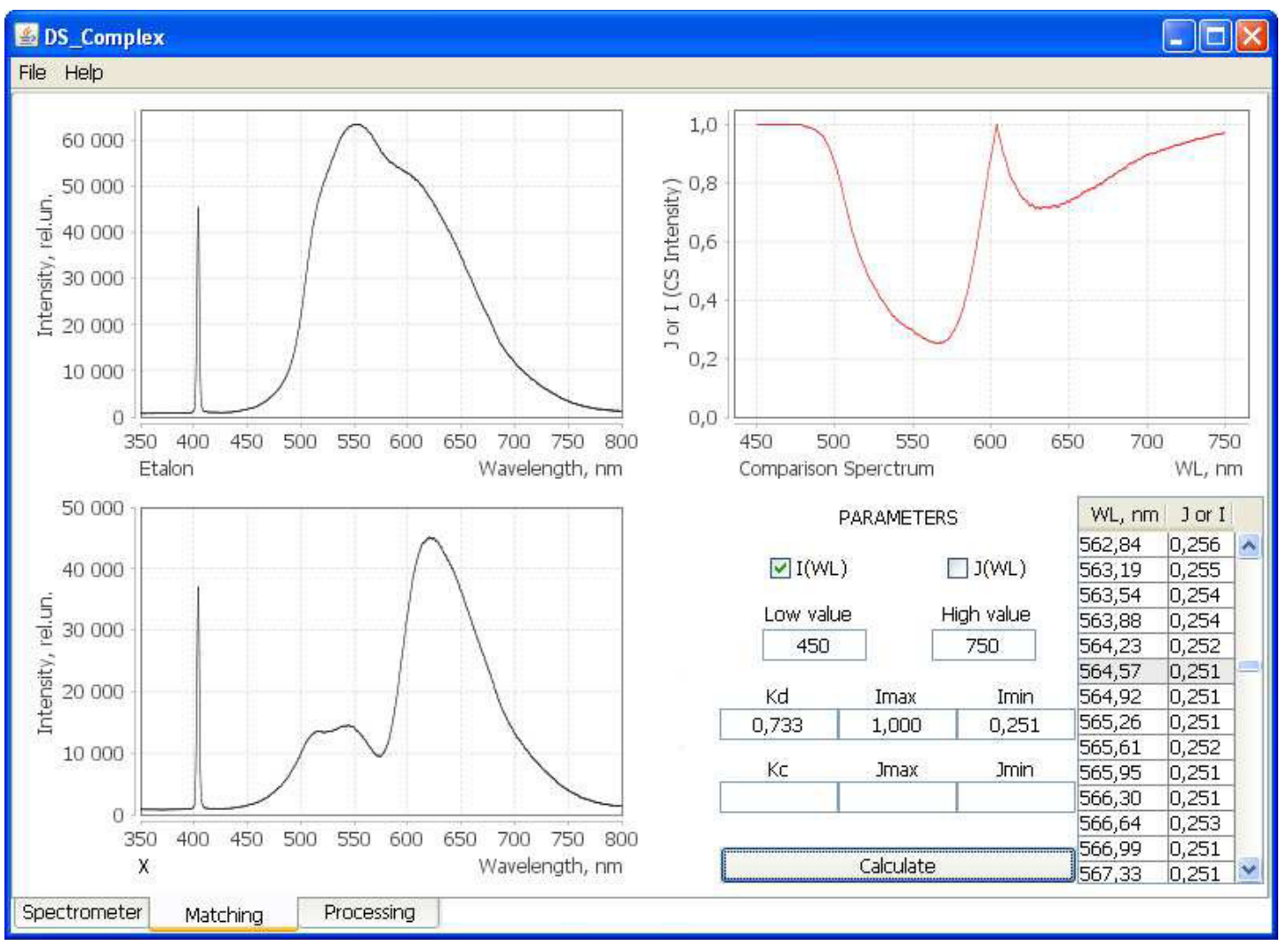

Рис. 3. Вікно програми зі спектрами ФЛ червоного та жовтого паперу та їх РС

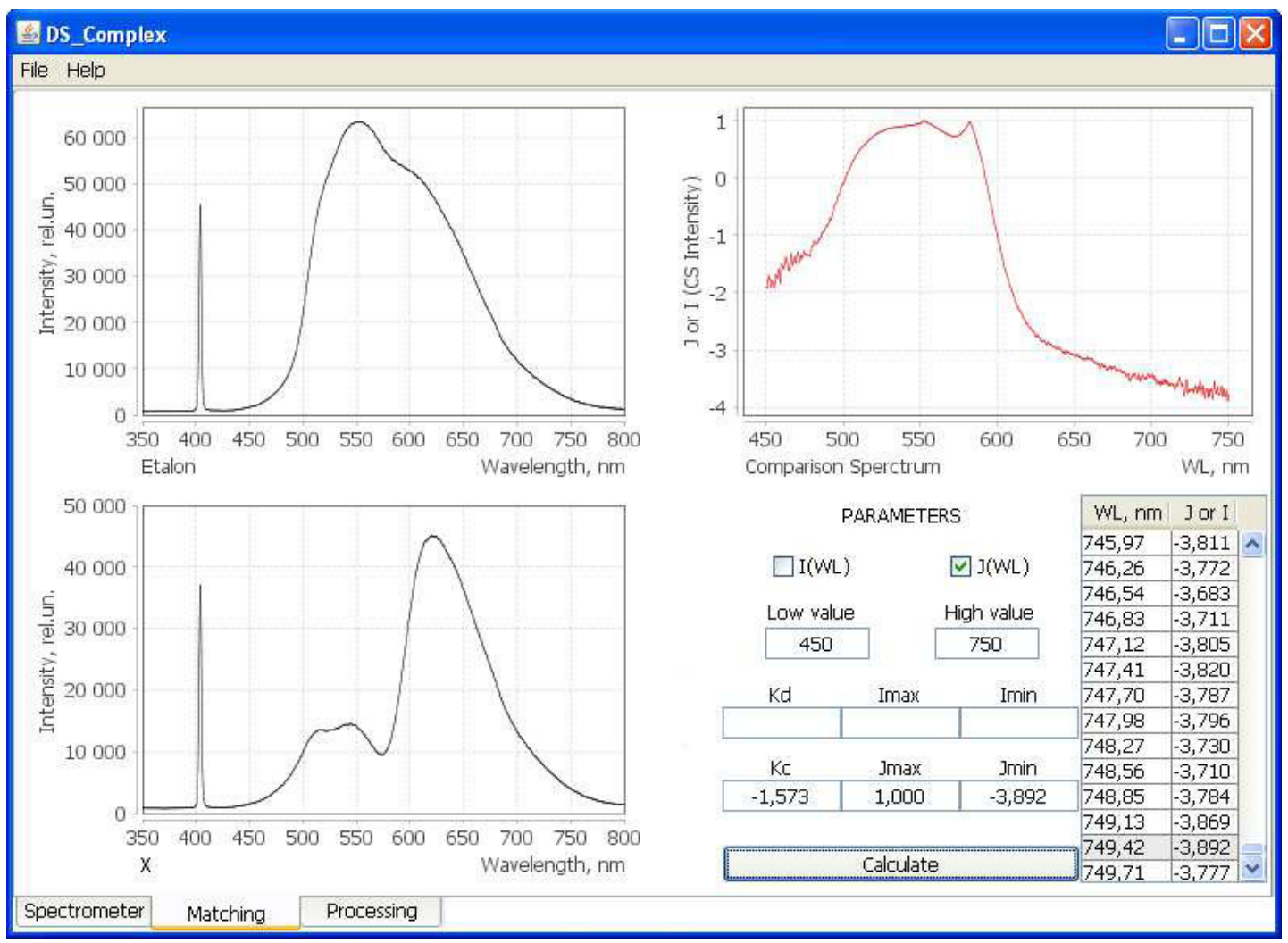

Рис. 4. Вікно програми зі спектрами ФЛ червоного та жсотого паперу та їх КС 
РС та КС були отримані при порівнянні спектрів ФЛ кольорового паперу - червоного та жовтого (вибирався як еталон). При цьому значення $\lambda_{E}$ покладалося рівним довжині хвилі прояву максимуму інтенсивності спектра еталона $I_{E \text { max }}^{\prime}$.

Набір компонентів GUI програми DS_Complex, що розташовувався на вкладці «Processing», дозволяв виконувати математичні операції додавання, вирахування, множення та ділення над спектрами джерел оптичного випромінювання, які були зареєстровані спектрометром BTC-110S. На початку роботи з ним при використанні меню «File» $\mathrm{COB}$ джерел $S a, S b$ завантажувалися 3 *.csv файлів і відображалися на панелі додатка. У той час перед розрахунком результуючого спектра $S r$ за допомогою повзунків GUI встановлювалися необхідні значення к коефіцієнтів А і В, які прямо пропорційно змінювали зареєстровану спектральну інтенсивність $S a$ і $S b$ (для всіх спектральних точок, які були оцифровані приладом), відповідно. Тип математичної обробки для одержання $S r$ визначався при включенні прапорця GUI вкладки «Processing», назва якого збігалася 3 виразом необхідної математичної операції. При обчисленні $\mathrm{Sr}$ за допомогою кожної математичної операції використовувалися пари значень спектральної інтенсивності $S a$ та $S b$ для оцифрованих точок цих спектрів, які мали однакові довжини хвиль.

Після натискання на кнопку «Calculate» програма DS_Complex розраховувала спектр $\mathrm{Sr}$, який відображався в графічному вигляді на панелі додатка, а його дані поміщалися в таблицю. Спектр $S r$ можна було зберегти у файлі формату *.csv і при необхідності одержати до нього доступ за допомогою меню «File».

На рис. 5 як приклад зображене вікно програми DS_Complex при множенні спектра фотолюмінесценції жовтого паперу ( $S a$ ) на спектр ФЛ червоної ( $S b$ ).

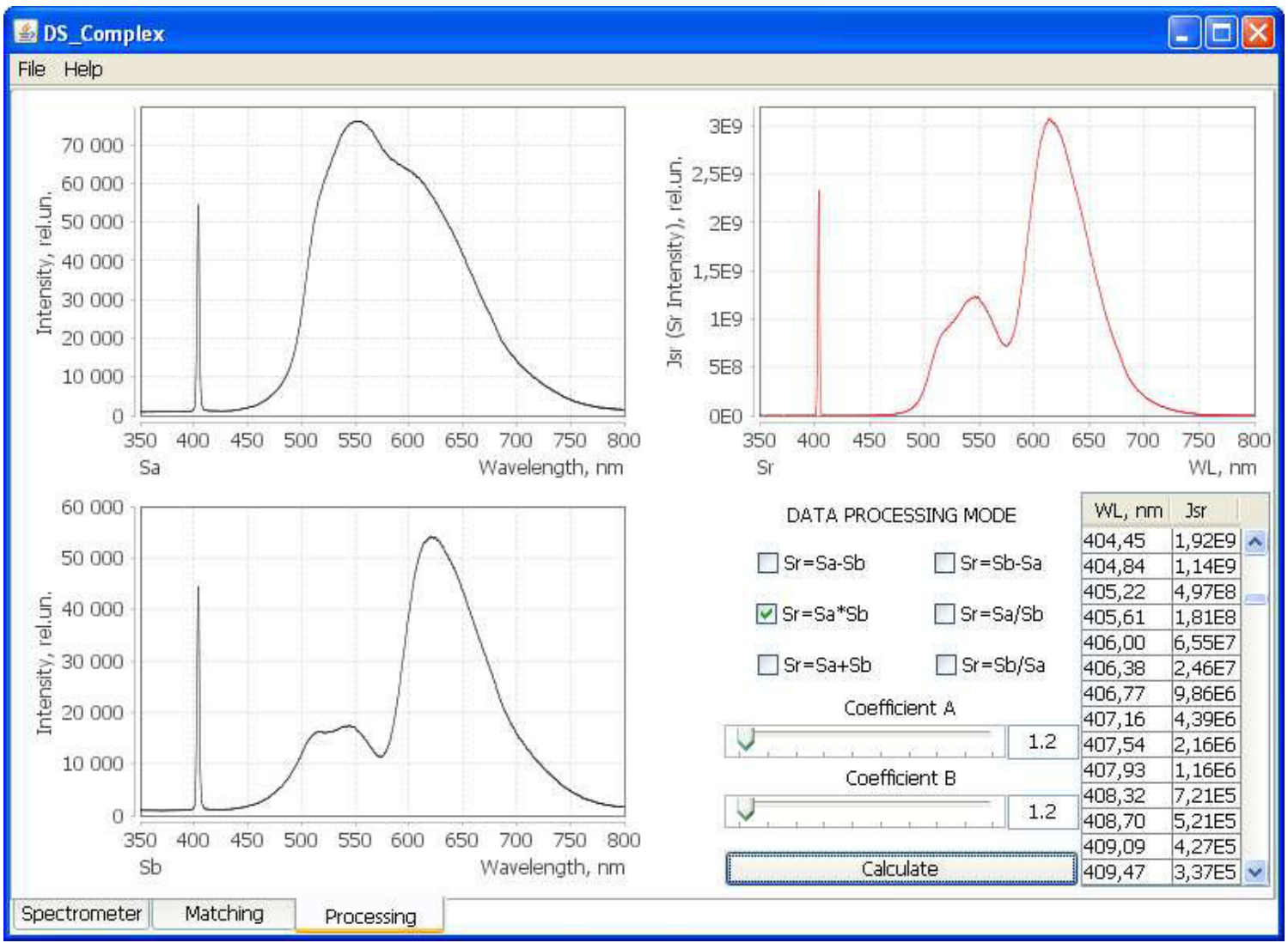

Pис. 5. Вікно програми DS_Complex

при множенні спектрів ФЛ червоного та жовтого паперу 
TECHNICAL SCIENCES AND TECHNOLOGIES

Висновки відповідно до статті. Таким чином, у цій роботі був розроблений кросплатформний Java-додаток DS_Complex (прикладне ПЗ) для реєстрації спектрометром BTC-110S спектрів джерел оптичного випромінювання в однократному та безперервному режимі, а також кількісного порівняння і обробки за допомогою арифметичних операцій спектральних даних об’єктів дослідження.

При кількісному порівнянні спектрів об'єктів дослідження програмою визначаються коефіцієнти відповідності для їх різницевого та кореляційного спектра.

Надалі передбачається модернізувати Јаvа-додаток DS_Complex, зокрема, забезпечити можливість його роботи в бінарному режимі обміну даними зі спектрометром BTC-110S.

\section{Список використаних джерел}

1. Spectrometers. URL: http://www.science-surplus.com/products/spectrometers.

2. Hopkins Jeffrey L. Using Commercial Amateur Astronomical Spectrographs. Hopkins. London : Springer, 2013. $286 \mathrm{p}$.

3. Кобелев Д. И., Иордан В. И. Разработка программного комплекса для управления спектрометром BTC-110S. Ломоносовские чтения на Алтае: фундаментальные проблемы науки и образования : сборник научных статей международной конференции (20-24 октября 2015 г., г. Барнаул). Барнаул : Изд-во АлтГУ, 2015. С. 1109-1114.

4. Иордан В. И., Кобелев В. И., Лапин А. А. Программный комплекс для регистрации и первичной обработки спектрограмм источников оптического излучения в процессе их регистрации спектрометром ВТС-110S. Многоядерные прочессоры, параллельное программирование, ПЛИС, системы обработки сигналов. 2017. № 7. С. 220-227.

5. Умаров М. Ф., Горелик В. С. Оптическая спектроскопия биоактивных препаратов. Вологда : ВоГУ, 2014. $147 \mathrm{c.}$

6. Voinov Yu. P., Gorelik V. S., Umarov M. F., Morozova S. V. Difference fluorescence spectroscopy of the structure and composition of bioactive preparations. Bulletin of the Lebedev Physics Institute. 2011. Vol. 38, No. 11. P. 323-327.

7. TIOBE Index for August 2020. URL: https://www.tiobe.com/tiobe-index/.

8. Точилін С. Д. Кросплатформне прикладне програмне забезпечення для спектрометра ВТС110S. Міжнародний науковий журнал «Інтернаука». 2019. Т. 1, № 5 (67). С. 45-50.

\section{References}

1. Spectrometers. (n.d.). www.science-surplus.com. http://www.science-surplus.com/products/ spectrometers.

2. Hopkins, Jeffrey L. (2013). Using Commercial Amateur Astronomical Spectrographs. Springer.

3. Jordan, V. I., Kobelev, D. I. (2015). Razrabotka programmnogo kompleksa dlya upravleniya spektrometrom BTC-110S [Development of a software package for controlling the BTC-110S spectrometer]. In Lomonosov Readings in Altai: Fundamental Problems of Science and EducationLomonosov's reading in altai: fundamental problems of science and education: Proceedings of an international conference : collection of scientific articles of the international conference (Oktober 2024, 2015, Barnaul) (pp. 1109-1114). Barnaul, ASU.

4. Jordan, V. I., Kobelev, D. I., Lapin, A. A. (2017). Programmnyy kompleks dlya registratsii i pervichnoy obrabotki cpektrogramm istochnikov opticheskogo izlucheniya $\mathrm{s}$ ispol'zovaniyem spektrometra BTC-110S [Software complex for registration and of primary processing spectrograms of optical radiation sources using the BTC-110S spectrometer]. Mnogoiadernye protsessory, parallelnoe programmirovanie, PLIS, sistemy obrabotki signalov-Multi-core processors, parallel programming, FPGAs, signal processing systems, 7, pp. 220-227.

5. Umarov, M. F., Gorelik. V. S. (2014). Opticheskaia spektroskopiia bioaktivnykh preparatov [Optical spectroscopy of bioactive drugs].VSU.

6. Voinov, Yu. P., Gorelik, V. S., Umarov, M. F., Morozova, S. V. (2011) Difference fluorescence spectroscopy of the structure and composition of bioactive preparations. Bulletin of the Lebedev Physics Institute, 38(11), pp. 323-327.

7. TIOBE Index for August 2020 (n.d.). www.tiobe.com. https://www.tiobe.com/tiobe-index. 
8. Tochilin, S. D. (2019). Krosplatformne prykladne prohramne zabezpechennya dlya spektrometra BTC-110S [Cross-platform application software for the BTC-110S spectrometer]. Mizhnarodnyy naukovyy zhurnal «Internauka» - International scientific journal «Internauka», 1(5(67)), pp. 45-50.

UDC 004.42:535.361

\section{Sergei Tochilin}

\section{APPLIED SOFTWARE FOR FIBER OPTICAL DIGITAL SPECTROMETER BTC-110S}

Urgency of the research. Spectral instruments are widely used in scientific and applied optical research. Modern spectral instruments in many cases are digital. The development of application software for digital spectral instruments is an urgent task.

Target setting. Typically, companies that manufacture spectral equipment supply digital spectral instruments and application software as a set. In some cases, the use of this software is tied to a specific platform. The application software for the BTC-110S spectrometer has similar features. In addition, the software that comes with the devices may not include the necessary spectral data processing procedures for optical studies.

Actual scientific researches and issues analysis. Currently, one of the most popular programming languages is Java. Recently, the cross-platform program ST Complex, an application software for the BTC-110S spectrometer, has been developed in the Java programming language.

Uninvestigated parts of general matters defining. The ST_Complex program has several limitations. It allows the BTC$110 S$ spectrometer to record radiation spectra only in a single mode. In addition, when processing spectral data, it is not possible to find the results of multiplying and dividing the spectra into each other, as well as determining the correlation spectrum and its correspondence coefficient.

The research objective. In this work, the task was to develop a Java application that can be used for recording radiation spectra in a single and continuous mode with the BTC-110S spectrometer, as well as for quantitative comparison and processing of spectral data of objects of study using arithmetic operations. Moreover, to compare the spectra of optical radiation sources, use the coefficients of correspondence of their difference and correlation spectra.

The statement of basic materials. The features of functioning and the graphical user interface of a Java application that solves the problem are described. Examples of its use are given.

Conclusions. A cross-platform application software has been developed for recording radiation spectra in a single and continuous mode with the BTC-110S spectrometer, as well as for quantitative comparison and processing using arithmetic operations of spectral data of research objects. When comparing the spectra of objects of study, the program determines the correspondence coefficients for their difference and correlation spectra.

Keywords: spectrometer; spectrum; application software.

Fig.: 5. References: 8.

| Точилін Сергій Дмитрович - кандидат фізико-математичних наук, доцент, доцент кафедри комп'ютерних систем та мереж, Національний університет «Запорізька політехніка» (вул. Жуковського, 64, м. Запоріжжя, 69093, Україна).

Tochilin Sergei - PhD in Physico-Mathematical Sciences, Associate Professor, Associate Professor of Department of Computer Systems and Networks, Zaporizhzhia Polytechnic National University (64 Zhukovsky Str., 69063 Zaporizhzhya, Ukraine).

E-mail: tochnozp@gmail.com.

ORCID: http//orcid.org/0000-0003-2010-6358

Scopus Author ID: 6602607112

Точилін C. Прикладне програмне забезпечення для оптоволоконного цифрового спектрометра BTC-110S. Технічні науки та технопогіï. 2020. № 3 (21). С. 154-162. 